\title{
稀有なる後縦靱帯骨化症の一例
}

$\begin{array}{cccc}\text { 九大整形外科教室 } & & \\ \text { 増 } & \text { 田 } & \text { 祥 } & \text { 男 } \\ \text { 諸 } & \text { 岡 } & \text { 正 } & \text { 明 } \\ \text { 竹 } & \text { 光 } & \text { 義 } & \text { 治 }\end{array}$

\section{A Rare Case of Broad Ossification of the Posterior Longitudinal Ligament with Severe Paraplegia.}

By

\author{
S. Masuda, M. Morooka \& Y. Takemitsu \\ Department of Orthopaedic Surgery, Faculty of Medicine \\ Kyushu University.
}

\begin{abstract}
A 48 year old woman. Her early complaint was difficulty in walking. One year previously the patient first complained low back pain. These complaints increased gradually, being accompanied by sensory disturbances of the lower extremities. Two months later she felt clumsiness in the legs and gradually became incapable of standing.

On X-ray and surgical findings broad ossification of the posterior longitudinal ligament were observed mainly in the thoracic and also in the lumbar region being accompanied by those of other spinal ligaments, such as anterior and interspinous ligament, as well as ligamenta flava.
\end{abstract}

頸椎後縦勒帯骨化症は 本邦では 1960 年月本の 報告 以来, 多数報告されている. てれらの大多数か頸椎ま たは上部胸椎を主とし，腰椎部まで及んでいるのは稀 である.われわれの経験した多くの症例も，そのほ之 んぞが頸椎および上部胸椎に限局している，今回，わ れわれは，胸椎を中心とし腰椎まで後縦靱带骨化を来 たした症例を経験したので報告する.

\section{症例 48 才の主婦.}

主訴 歩行できない。

前病歷 家族歷には特記すべきことなし.

現病歷 約 1 年前より誘因なく右傍腰部に疼痛を来 たし次第に増強，両下肢の冷感を伴ってきた. 約 2 力 月後, 両下肢が重たくなり長歩きすると脚があつれる ようになった. 1 力月後には歩行が不自由となり家事 ができず，起立不能となって入院た.

入院時所見 体格大, 肥満体, 局所所見は頸部に特 に異常なく, 第 7 胸椎中心にやや刍背あり, 同部に圧 痛がある. 胸椎腰椎は強直, 上肢には特に異常なく, 下肢での筋力低下は著明, 反射は上下肢共に六進し,
下肢での反射六進は著明である. 病的反射ではワルテ ンベルグ, バビンスキーは両側, 共に陽性である. 知 覚障害は, 両側共, 第 9 胸椎の高さより知覚鈍麻あ り, 足部には異常知覚がある.

検查所見 血沈, やや元進, 低色素性貧血あり, ASLO CRP RA 異常なし, 尿に糖は検出されない. EMG では下肢に NMU の減少を見る.

レントゲン所見 第 6,7 胸椎間にて軽度側彎あり， 同部には椎間板変性がある. 前縦勒帯骨化が, 第 2 , $33,44,5$ 腰椎間にあり, 後縦勒带骨化は第 3 胸 椎より第 3 腰椎まで認められる. この他, 第 7 胸椎よ り第 1 仙椎まで黄勒帯に相当すると思われるもの, お よび第 7 胸椎より第 2 腰椎までの棘間, 棘上勒帯の骨 化が認められる (第 $1 ， 2$ 図). 仙腸関節の癒合はな く, 四肢の他の関節にも異常を認めない.

ミエログラィー所見では, 第 4 靧椎部より第 2 腰 椎部までの 通過障害があり, 頸椎の後屈で第 4 頸椎 部で完全ブロックされる. 手術所見としては Myelography でもっとも通過障害の強い頸椎部で, 第 3 頸 


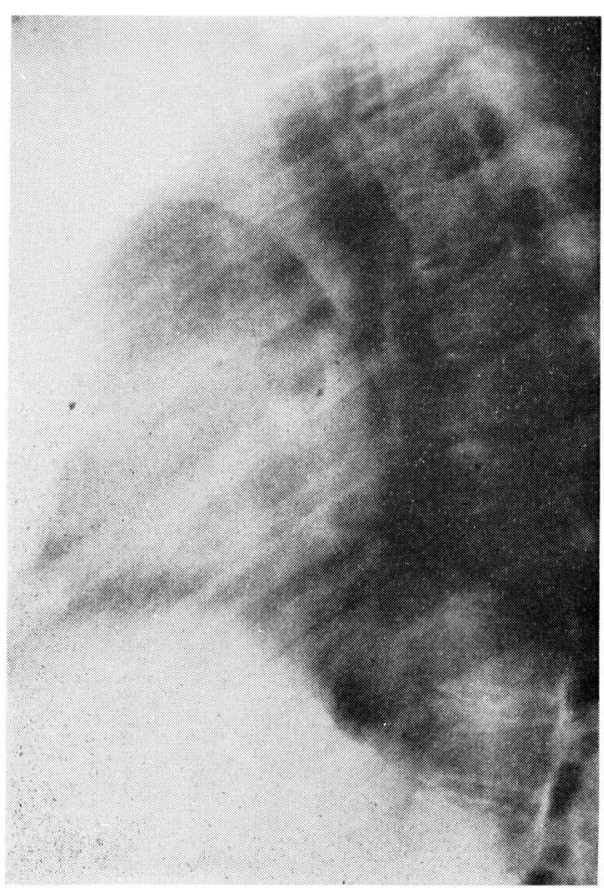

図1

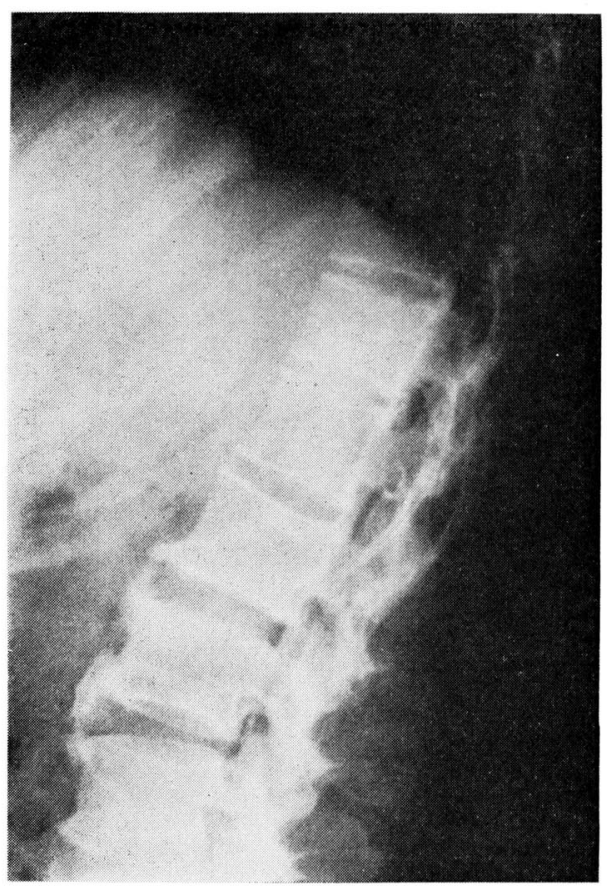

椎より第 6 頸椎までの椎弓切除術を行ったととろ黄勒 帯に異常なく，硬膜の拍動は著明ではないが，わずか に見られた. 術後, 知覚障害は軽減し異常知覚は消失 し, 経過は一時的には良好であった. 術後 4 週より起 座を許可し，機能訓練を行ったところ，再び症状は増 悪し，異常知覚が再現したので再び Myelography を 行った． 透視台にて傾斜を増しても，第 10 胸椎か ら, 第 1 腰椎に至るまで造影剂の通過か障害され，狭 少であったため同部の椎弓切除術を行った．棘上，棘 間勒帯は骨様を呈し，黄靯帯む椎弓板より硬い骨様組 織を呈し，硬膜外脂肪組織は全く消失している．乙れ らの切除を行うことにより硬膜内は明らかなる除圧効 果を呈した，術後, 膝関節以下の知覚鈍麻, また異常知 覚は軽減したが, 滕窩部の疼痛と腓腹筋の twitching が残り，後療法を行うあ疼痛のため運動が因難とな り，筋力は低下し，術後 10 週を経過しても回復しな いので，第三回の除圧手術を予定している.

考按

広範囲の 後縦勒帯, 骨化症例は, 番場が 第 5 頸椎よ り，第 12 胸椎までの 1 例を報告している．また土屋 は第 4 胝椎より，第 3 腰椎までの後縱勒帯に骨化を来 たした 1 剖唡例を報告している. そのいずれも，上ま たは下の前綐靯帯の骨化を伴っている. また 1967 年, 恩地は 18 例中 2 例に胸腰椎部の posterior paravertebral ossifcation を報告している. 本年の整形 外科学会総会でも, 広範な脊椎靮帯の骨化症例が報告 された. 本症例も後䋛靱帯をはじめ, 広範な勒帯の骨 化を来たして抢り, 従来, 報告されている後縦勒帯骨 化症とは別の咨患と屯考元らる. 類似の疾患として は, 変形性脊椎症, 強直性脊椎炎の各型, Forestier 氏病などをあげねばならないが，それぞれ，骨化機 序, 罹患部位と炎症反応の 有無, 局在部位などを考 えるとそれらのいずれとも考え難く，Spondylosis ligamentosa ossificans の範疇には属するが， その 病型分類については今後の研究に待たねばならない.

図 2 


\section{参考文献}

1）番場 - 他：臨整外，4, 375, 1969.

2) Minagi : Radiology, 105, 365, 1969.
3) Onji : J.B.J.S., 49-A, 1314, 1967.

4）月本：日整会誌，34,107, 1960 .

5）土屋・他：整外， 21, 768, 1970.

脊髄腫瘍 の 4 例

国立別府病院整形外科

増 田元 彦 - 脇 丸俊 博

直野敬・藤井敏男

内 村 正 英 $\cdot$ 江 崎 正 孝

\title{
Four Cases of the Spinal Cord Tumor
}

By

\author{
M. Masuda, T. Wakimaru, T. Naono,
} T. Fujii, M. Uchimura \& M. Ezaki

Division of Orthopedic Surgery Beppu National Hospital

We report the four cases of the spinal cord tumor which we have experienced recently.

Case 1. female ...... aged fifty was a neurinoma occured in the canda equina.

Case 2. female ...... aged thiry five was a epidermal cyst occured in the nineth thoracic vertebral region.

Case 3. male …. aged fifty seven intramedullary astrocytoma which occured in the region of the fourth thoracic vertebrae.

Case 4. female $\cdots .$. aged eighteen was a meningioma occured in the extradural space of the fourth and fifth thoracic vertebrae.

In the case 1. 2. 4. tumors were operatively almost completely resected, but in the case 3. unable to resect. Consequently in the former, symptom (sensory and motor disturbance) has obviously improved and deminished, but in the latter not improved and deteriorated.

脊髄腫瘍は 1887 年, Gowers と Horsley が最初 に診断し，摘出に成功し，わが国では，1911年，武 谷と三宅が初めて診断し, 摘出に成功して以来, わが 国の文献にみる脊髄腫瘍の報告例は既に数百例を数え える. そしててれらの症例の集計から，脊髄腫瘍の臨 床像, 診断, 治療に関しては, ほぼ完全な考察がなさ れ，それに基づき早期診断，早期摘出が行われるよう になり，良好な予後を期待できるようになった．われ われは最近脊骾腫湯の 4 例を経験したので報告する.

症例 150 才, 主婦.

既往歴 高血圧症

主訴 腰痛, 両下肢痛
現病歴 昭和 44 年 7 月ごろより，歩行時右下肢が 前に出にくいようなととが時々あった. 昭和 45 年 1 月，風邪をひき，咳嗽時腰痛あり，2月に両下肢にき りきりする疼痛あり, 内服薬の投与をうけたが効果が なかった. 3 月上旬, 頸が動きにくくなり, 無理に動 かすと腰より両下肢にかけて疼痛が惹起された. 同時 に下肢の運動, 歩行むぎこちなくなった. 近医に入院

し, 骨盤牽引，ギプス床安静などの 治療で疼痛軽減 し，步行も可能となり退院したが，7月になり再び同 様の症状が再発したので, 7 月 20 日 当院整形外科に 入院した.

入院時所見 食欲不振のためるい馊を認める. 脊柱 